\title{
Allozyme Electrophoretic Technique and Phylogenetic Relationships in Three Species of Sepia (Cephalopoda: Sepiidae)
}

\author{
M. Perez-Losada, ${ }^{1}$ A. Guerra ${ }^{2}$ and A. Sanjuan ${ }^{1}$ \\ ${ }^{1}$ XENÉTICA EVOLUTIVA MOLECULAR, FACULTADE DE CIENCIAS- \\ BIOLOXIA, APDO. 874, UNIVERSIDADE DE VIGO, E-36200 VIGO, SPAIN AND \\ ${ }^{2}$ INSTITUTO DE INVESTIGACIONES MARINAS (CSIC), EDUARDO CABELLO \\ 6, E-36208 VIGO, SPAIN
}

Correspondence to: Andres Sanjuan, Xenetica Evolutiva Molecular, Facultade de Ciencias-Bioloxia, Apdo. 874, Universidade de Vigo, E-36200 Vigo, Spain, Fax: $34+$ 86+812556, E-mail: sanjuan@seinv.cesga.es

\begin{abstract}
Samples of Sepia officinalis, S. orbignyana, and S. elegans from Galician waters (NW Iberian Peninsula) were obtained from commercial catches in three fishing ports. A preliminary screening for 47 and 33 enzymes in mantle muscle and digestive gland, respectively, was carried out using seven buffer systems. Thirty-seven enzyme loci were resolved from these tissues using only two buffer systems. Most enzymes showed equal or higher activity for the digestive gland than for the mantle muscle in freshly-caught samples of S. officinalis and S. orbignyana. The activity of a large number of enzymes decreased faster in the digestive gland than in the mantle muscle after 6-12 $\mathrm{h}$ at room temperature. Consequently, we suggest that mantle muscle rather than digestive gland be used for routine electrophoretic studies in Sepia species obtained from commercial catches. A phylogenetic reconstruction analysis, applying the Wagner parsimony method and using the ommastrephid species Illex coindetii as outgroup, showed only one most parsimonious tree. S. orbignyana and S. elegans were found to be a sister group. The topology agreed with that recently obtained from mitochondrial rDNA sequences, and both molecular data are in line with previous morphological results. They confirm the view that S. orbignyana and S. elegans belong to a different subgenus (Rhombosepion) from that of S. officinalis (Sepia "sensu stricto").
\end{abstract}

KEY WORDS. Cephalopoda, Sepia officinalis, S. orbignyana, S. elegans, Rhombosepion, enzyme activity, phylogeny, North-Eastern Atlantic Ocean 


\section{INTRODUCTION}

The Genus Sepia Linnaeus 1758, order Sepioidea (Mollusca: Cephalopoda), has some systematic and phylogenetic problems. S. officinalis (Linnaeus, 1758), S. orbignyana (Férussac, 1826) and S. elegans (Blainville, 1827), have been catalogued by Khromov (31) into two different subgenera on the basis of the internal cone structure and the shape of the cuttlebone. S. officinalis was considered to belong to the subgenus Sepia "sensu stricto," whereas S. orbignyana and S. elegans were classified in the subgenus Rhombosepion Rochebrune, 1884. The validity of these, and another four Sepia subgenera, has been discussed by Khromov et al. (32). Recently, phylogenetic mitochondrial rDNA studies for 27 decapod cephalopods have indicated that $\mathrm{S}$. orbignyana and S. elegans are a monophyletic group, separated from S. officinalis (5).

Data on genetic variability obtained from allozyme polymorphisms have proved to be effective for detection of genetic differences at the inter and intraspecific level in commercially exploited fish and cephalopod species $(13,15,28,49)$. There have been 21 allozyme studies of cephalopods, which have included ten Loliginidae, ten Ommastrephidae, one Gonatidae, two Octopodidae and one Nautilidae species $(12,15,30,50)$. However, as yet, allozyme polymorphism analyses have not been applied to species of the order Sepioidea. This paper examines three species which represent an important commercial resource throughout their range; combined catches being around 75,000 metric tons (20). The limited dispersive capacity of these species, in contrast with oceanic squids (26), may result in some degree of regional intraspecific genetic differentiation.

The first aim of this paper was to develop horizontal starch gel electrophoresis technique for Sepia officinalis, S. orbignyana, and S. elegans collected from commercial catches, testing enzyme activity in mantle muscle and digestive gland, and after various storage times at room temperature. This will allow studies of the inter and intraspecific genetic variability in these species in the future. The second aim was to determine the phylogenetic relationships among the three Sepia species. 
Samples of Sepia officinalis, S. orbignyana, and S. elegans and also of Illex coindetti (Vérany, 1839) for comparison, were obtained from Galician waters (NW Iberian Peninsula) by fishing vessels using traps for S. officinalis, and bottom trawl for the other species. Specimens were collected from commercial catches in three fishing ports as soon as the fishing vessels tied-up (1-24 h after animals were caught). S. officinalis individuals were collected in Vigo, S. orbignyana in Ribeira and S. elegans and I. coindetii in Celeiro (Fig. 1). Fifteen individuals for each species were taken to develop the electrophoretic technique. Subsequently, ten individuals for each species were collected from very freshly commercial catches (1-8 h after animals were caught) for routine electrophoretic analyses. The specimens were sorted and placed into plastic bags, immediately frozen in dry ice and transported to the laboratory, where they were stored at $-75^{\circ} \mathrm{C}$ until required.

Horizontal starch gel electrophoresis based on the method of Harris and Hopkinson (27) and Murphy et al. (35) was carried out. Samples of mantle muscle from the three Sepia species were prepared for electrophoresis by first removing the skin and by rinsing off ink residues. About $60 \mathrm{mg}$ of mantle muscle or digestive gland was homogenized with $70 \mu \mathrm{L}$ of $0.01 \mathrm{M}$ dithiotreitol (DTT) solution for S. officinalis, and with $50 \mu \mathrm{L}$ for S. orbignyana and S. elegans, because the mantle muscle of the first species was more viscous than those of the two latter cuttlefishes. The homogenate was centrifuged at $12,000 \times \mathrm{g}$ for $10 \mathrm{~min}$ at $4^{\circ} \mathrm{C}$ and soaked onto $5 \times 11 \mathrm{~mm}$ strips of Whatman No 3 paper, except for investigations of ARK and GPI where Whatman No 1 was used to avoid broad smears. Seven buffer systems and different gel buffer solutions were assessed: 1) continuous Tris-Borate-EDTA pH 8.7 (8), with gel buffers at $1: 4$ and 1:9 dilutions of electrode buffer; 2) continuous Tris-Citrate $\mathrm{pH} 8.0$ (48), with gel buffers at 1:9, 1:14, 1:19, and 1:26 dilutions of electrode buffer; 3 ) continuous Acetate $\mathrm{pH} 5.6$ (44), with gel buffers at 1:9,1:12, and 1:25 dilutions of electrode buffer; 4) continuous Tris-Citrate pH 7.0 (modificated of Ahmad et al. (1), with gel buffers at 1:9, 1:14 and 1:19 dilutions of electrode buffer; 5) continuous Tris-Maleate-EDTA pH 7.4 (9), with gel buffer at 1:9 dilution of electrode buffer; 6) discontinuous Histidine-Citrate (23); and 7) discontinuous Lithium-Hidroxide (42). Starch gels (20 x $18 \times 1 \mathrm{~cm})$ of $12 \%$ hydrolyzed starch (SIGMA S-4501) were run at $4^{\circ} \mathrm{C}$ at constant voltage depending of the enzyme system. After electrophoresis gels were sliced into six and stained for 
distinct enzymes, except the top slice. Most enzymes were visualized by the histochemical staining recipes of Murphy et al. (35), with the exception of PGM (44), ACP, DDH, MPI and PK (27) and ESTD and PEP (1). Forty-seven and 33 enzymes were screened for the mantle muscle and the digestive gland, respectively, using the seven buffer systems. A total of 26 enzymes showed enough activity and resolution to be genetically interpreted using the Tris-Borate-EDTA pH 8.7 (8; electrode buffer: 180 mM Tris, 100 mM Boric acid, 4 mM EDTA; gel buffer: 1:4 dilution of electrode buffer) and the Tris-Citrate $\mathrm{pH} 8.0$ (48; electrode buffer: $250 \mathrm{mM}$ Tris, $57 \mathrm{mM}$ Citric acid; gel buffer: 1:9 dilution of the electrode buffer) buffer systems (Table 1). These two buffer systems and 26 enzymes were selected for the routine scoring of allozyme genotypes. Terminology and notations for isozymes/allozymes were based on recommendations of Shaklee et al. (43) and IUBMB (29). Arabic numerical suffixes for multiple loci (1, 2, ...) were in order of decreasing anodal mobility. Alleles were identified by relative electrophoretic mobilities, being $* 100$ the most common allele in S. officinalis.

The type of tissue and the sampling time after death can have an effect on the enzyme activity and the banding pattern of isozymes $(18,19,27)$. In order to test the tissue type, the electrophoretically detected enzyme activities of 26 enzymes from freshly-caught samples of the digestive gland and the mantle muscle of S. officinalis and S. orbignyana were compared. In addition, the influence of time passed at room temperature, which can resemble the sampling time after death, was checked for the 26 enzymes in both tissues. The mantle muscle and the digestive gland from each $\mathrm{S}$. officinalis and $\mathrm{S}$. orbignyana were divided in three and four pieces, respectively, and kept at room temperature $\left(20^{\circ} \mathrm{C}\right)$ for $6 \mathrm{~h}, 12 \mathrm{~h}$ (only for the digestive gland) and $24 \mathrm{~h}$, prior to electrophoresis. Sample strips were loaded on the same gel for each species, and the relative enzyme activities were measured by visual observation of the staining intensity on the gel (see Fig. 2). In this study, S. elegans was not included because this species showed similar enzyme activities to S. orbignyana in the preliminary screening.

Genotype frequencies at polymorphic loci were tested for conformance to HardyWeinberg equilibrium expectations by chi-square tests. Average heterozygosities $(\mathrm{H})$, average number of alleles $(\mathrm{Na})$ and proportion of polymorphic loci using the 0.95 criterion $(\mathrm{P})$ were calculated for each species (36). 
A phylogenetic reconstruction analysis using the Wagner parsimony method $(21,33)$ was carried out with the MIX (Mixed Method Parsimony) routine of the Phylip 3.5c computer program (22). Individual alleles were considered as separate characters with their presence and absence as alternative states. One hundred and eighteen characters were considered per species. The ommastrephid species Illex coindetii was used as outgroup to root the tree.

\section{RESULTS AND DISCUSSION}

Twenty-six enzymes from the mantle muscle and the digestive gland of Sepia officinalis, S. orbignyana, and S. elegans were electrophoretically assayed and gave sufficient activity and good enough resolution for regular interpretation of banding patterns. Twenty-five enzymes were resolved for the mantle muscle of the three Sepia species, and 22 and 20 for the digestive gland of S. officinalis and S. orbignyana respectively (Tables 1 and 2). Isozyme patterns were interpreted on the basis of known quaternary structure in other organisms $(27,34,35,39)$.

Seventeen enzymes gave a single anodic zone of activity for at least one tissue from the three Sepia species (Tables 1 and 2). For DDH and FBALD a weak cathodic sub-band, which could not be interpreted, was detected on the gel. ESTD showed a higher enzyme activity in the lowest gel layer than in any other. Each primary band was accompanied by a faint cathodic sub-band in S. officinalis, and by an anodic one in S. orbignyana and S. elegans. Three-banded ESTD heterozygotes were found for S. elegans, as typical for a dimeric enzyme. A dimeric esterase, which could correspond with ESTD, has been also reported for Loligo vulgaris (EST-1; (2)) and Berryteuthis roadster (EST-2; (30)). IDDH showed a cathodic subband which could not be interpreted. Five-banded IDDH heterozygotes were found for S. officinalis and S. elegans, as typical for a tetrameric enzyme. A monomeric IDDH has been described for the mantle muscle of L. forbesi (11); therefore the IDDH structure seems to vary according to the cephalopod species. The LAP stain also highlighted PEPB and consequently a control slice from the same gel was specifically stained for PEPB to distinguish the LAP and PEPB activity bands. LDH exhibited activity only for the digestive gland. This result agrees with those reported by Storey (45) and Dando et al. (17) concerning a higher LDH activity for the digestive gland than for the mantle muscle in S. officinalis. Low levels of LDH activity 
have been found for the mantle muscle of other cephalopods (41). PEPB and PGM showed two-banded heterozygotes for S. elegans, which suggested a monomeric structure, typical for these enzymes. The same structure has been observed for PGM in L. forbesi (11), L. gahi (14), L. vulgaris (2) and B. magister (30). SOD showed each primary band accompanied by a faint cathodic sub-band in S. officinalis.

Nine enzymes showed two or three anodic zones of similar or different activity for at least one tissue from the three Sepia species (Tables 1 and 2). Two AAT activity zones appeared when the gel was run for $17 \mathrm{~h}$ at $5.4 \mathrm{~V} / \mathrm{cm}$, AAT-2 appearing very close to the origin (see Fig. 2). The staining solution was modified with respect to the original stain to obtain sufficient enzyme activity (modified amounts: $0.5 \mathrm{~g}$ of L-aspartic acid, $0.2 \mathrm{~g}$ of $\alpha$-ketoglutaric acid and $75 \mathrm{mg}$ of fast blue BB salt; (35)). AAT-2 showed three-banded heterozygotes for S. orbignyana and S. elegans, which suggested a dimeric structure, as usual for this enzyme, and as detected for other cephalopods (Berryteuthis magister; (30)). The ACP staining solution was also modified ( $0.3 \mathrm{~g}$ of $\alpha$-naphtyl phosphate; 27$)$. ACP-3 presented two-banded heterozygotes in S. orbignyana, which suggested a monomeric structure, as described for the "red cell" ACP (27). To reveal EST it was necessary to pre-incubate the gel slice in the stain for 30 rain, before adding the fast blue BB salt. EST showed two activity zones for the mantle muscle: a stronger anodic EST-2 and a weaker less anodic zone, which was identified as ESTD. The MDH stain also highlighted MEP. To reduce the MEP reaction, $50 \mathrm{mg}$ of pyruvic acid was added to the MDH staining solution. OPDH did not exhibit activity for the digestive gland. OPDH activity for digestive gland decrease rapidly after freezing, probably due to proteolysis $(3,46)$. However, two OPDH activity zones were observed for the mantle muscle of the three Sepia spp. OPDH-1 showed two-banded heterozygotes in the three cuttlefishes, which conforms to the usual monomeric structure described for this enzyme in bivalves (Pecten maximus (38); and Tapes decussatus (40)) and cephalopods (S. officinalis $(4,45)$; and L. vulgaris (2)). Tissue-specific OPDH isozymes have been found and characterized in cephalopods (S. officinalis $(17,46,47)$; and Loligo vulgaris (24)) and, exceptionally, in the bivalve Tapes decussatus (40). Four possible OPDH isozymes, each for the muscle, heart, brain and digestive gland tissues were described in S. officinalis (46). Nevertheless, the results obtained here indicate that more than one "muscle type" OPDH could exist in Sepia spp. PK has rarely been employed on 
cephalopod studies, being assayed without success in L. gahi (14) and Illex argentinus (16).

Twenty-nine isozymes were detected for the digestive gland and 31 for the mantle muscle in S. officinalis (Table 2). Twenty-four isozymes were observed for both tissues (e.g., AAT-1), five only for the digestive gland (e.g., ACP-1), seven only for the mantle muscle (e.g., FBALD) and one (MEP-2) for neither tissue (Table 2). Of the 24 isozymes noted for both tissues, eight (33.3\%) showed the highest activity for the digestive gland (e.g., ACP-3, A3 for the digestive gland versus A2 for the mantle muscle), two (8.3\%) for the mantle muscle (e.g., ARK, A3 for the mantle muscle versus A2 for the digestive gland), and 14 (58.3\%) showed similar activity for both tissues (e.g., AAT-1, A3 for both tissues) (Table 2). A similar result was found in S. orbignyana, were 27 isozymes were detected for the digestive gland and 31 for the mantle muscle (Table 2). Twentytwo isozymes were observed for both tissues (e.g., AAT-1), five only for the digestive gland (e.g., ACP-1), nine only for the mantle muscle (e.g., AK) and one (IDHP-1) for neither tissue (Table 2). Of the 22 isozymes noted for both tissues, nine (40.9\%) showed the highest activity for the digestive gland (e.g., ACP-3, A3 for the digestive gland versus A2 for the mantle muscle), seven (31.8\%) for the mantle muscle (e.g., AAT-1, A3 for the mantle muscle versus A2 for the digestive gland), and six (27.3\%) showed similar activity for both tissues (e.g., AAT-2, A2 for both tissues) (Table 2). Consequently, in freshly-caught samples from both S. officinalis and S. orbignyana the enzyme activity seems to be higher for the isozymes of the digestive gland (33.3\% and $40.9 \%$, respectively) than those of the mantle muscle ( $8.3 \%$ and $31.8 \%$, respectively). This difference in enzyme activity could be due to a greater enzyme concentration for the digestive gland than for the mantle muscle, as usual for a large number of enzymes in marine molluscs.

After $24 \mathrm{~h} 100 \%$ of loci (31 isozymes) showed varying enzyme activity for the mantle muscle of both Sepia species, and 62\% (18 isozymes) and 48\% (13 isozymes) for the digestive gland of S. officinalis and S. orbignyana, respectively (Table 2). Therefore, sufficient enzyme activity in the mantle muscle was maintained for detection in all loci at $24 \mathrm{~h}$, whereas in the digestive gland $38 \%$ for S. officinalis and $52 \%$ for S. orbignyana were lost (Table 2). A faster decrease in activity for digestive gland from S. orbignyana than relative to $\mathrm{S}$. officinalis was observed. The digestive gland is the main organ 
involved in the synthesis and secretion of digestive enzymes in Sepia spp. $(6,7)$, and the greater concentration of digestive enzymes presumably have a higher proteolytic degradation in the digestive gland than in the mantle muscle. Consequently, we suggest the use of the mantle muscle rather than the digestive gland for routine electrophoresis of Sepia species obtained from commercial catches, because usually the time elapsed since the specimens are caught until the fishing vessels tied up range between $12 \mathrm{~h}$ and $24 \mathrm{~h}$.

The allozyme frequencies for 32 enzyme loci from the mantle muscle of Sepia officinalis, S. orbignyana, and S. elegans, and the ommastrephid species Illex coindetii are shown in Table 3. Most loci were monomorphic for each Sepia species, and three loci were fixed for the three species. Twelve loci were completely diagnostic among the three Sepia species, 14 between S. orbignyana and S. elegans, and 24 between S. officinalis and the other two cuttlefishes. No significant deviation from the HardyWeinberg expected proportions for any species at any polymorphic locus was detected by the chi-square tests (data not shown). The average heterozygosities $(\mathrm{H})$, the average number of alleles $(\mathrm{Na})$ and their standard errors (SE), and the proportion of polymorphic loci using the 0.95 criterion (P) are shown in Table 4. No significant differences were detected for the average heterozygosities among the three Sepia species using t-test (36). The average heterozygosity estimates fell within the range found for most cephalopods (see for review $(10,15,25,30)$ ) and below the average for invertebrate species $(0.10$; see (37)).

The phylogenetic reconstruction analysis showed only one most parsimonious tree with 123 minimum number of steps (Fig. 3). Sepia orbignyana and S. elegans made a sister group which shared a common ancestor not shared by S. officinalis. The topology of this phylogenetic reconstruction was in agreement with that obtained by Bonnaud et al. (5). According to Khromov (3I) and Khromov et al. (32) S. orbignyana and S. elegans would share a larger number of characters than with S. officinalis, and therefore the evolutionary divergence between them would also be smaller than that expected between S. officinalis and each of S. orbignyana and S. elegans. Phylogenetic reconstruction on molecular data, both at allozyme (this paper) and mtDNA levels (5) support this hypothesis, since S. officinalis seems to have been reproductively isolated 
in a first evolutionary event and the S. orbignyana and S. elegans monoplyletic group in a second.

We are grateful to Fernando Casas and other A. G. research team members (B. G.

Castro, A. F. Gonzalez, M. Rasero, and F. Rocha) for assistance in the collection of the cuttlefish samples and helpful discussion. Thanks are also due to P. J. Smith and two anonymous referees for valuable suggestions. This research was made possible by an equipment grant from the University of Vigo to M. Horjales and by the action of the Faculty Dean M. L. Andrade to build up the electrophoretic laboratory. This research was supported by the AIRI-CT92.0573 project of the EC. Portions of this paper fulfil the $\mathrm{PhD}$ requirements for M. P.-L. (University of Vigo), who received a scholarship from Xunta de Galicia (Spain).

References

1. Ahmad, M.; Skibinski, D.O.F.; Beardmore, J.A. An estimate of the amount of genetic variation in the common mussel Mytilus edulis. Biochem. Genet. 15: 833-846; 1977.

2. Augustyn, C.J.; Grant, W.S. Biochemical and morphological systematics of Loligo vulgaris vulgaris Lmk. and Loligo vulgaris reynaudii d'Orbigny nov. comb. (Cephalopoda: Myopsida). Malacologia 29: 215-231; 1988.

3. Ballantyne, J.S.; Hochachka, P.W.; Mommsen, T.P. Studies on the metabolism of the migratory squid, Loligo opalescens: enzymes of tissues and heart mitochondria. Mar. Biol. Lett. 2: 75-85; 1981.

4. Beaumont, A.R.; Day, T.R.; Gäde, G. Genetic variation at the octopine dehydrogenase locus in the adductor muscle of Cerastoderma edule (L.) and six other bivalves species. Mar. Biol. Lett. 1: 137-148; 1980.

5. Bonnaud, L.; Boucher-Rodoni, R.; Monnerot, M. Phylogeny of cephalopods based on partial 16S rDNA nucleotide sequences. C. R. Acad. Sci. Paris, Life Sci. 317: 581$588 ; 1994$.

6. Boucaud-Camou, E. Localisation d'activitds enzymatiques impliquées dans la digestion chez Sepia officinalis L. Arch. Zool. Exp. Gen. 115: 5-27; 1974. 
7. Boucaud-Camou, E.; Boucher-Rodoni, R. Feeding and digestion. In: Wilbur, K.M., ed. The mollusca, vol. 5. In: Salenddish, S.M.; Wilbur, K.M., eds. Physiology, pt. 2. Toronto: Academic Press; 1983: pp. 149-187.

8. Boyer, S.H.; Fainer, D.C.; Naughton, M.A. Myoglobin: inherited structural variation in man. Science 140: 1228-1231; 1963.

9. Brewer, G.J. An Introduction to Isozymes Techniques. New York: Academic Press; 1970.

10. Brierley, A.S.; Rodhouse, P.G.; Thorpe, J.P.; Clarke, M.R. Genetic evidence of population heterogeneity and cryptic speciation in the ommastrephid squid Martialia hyadesi from the Patagonian shelf and Antarctic Polar Frontal Zone. Mar. Biol. 116: 593-602; 1993.

11. Brierley, A.S.; Thorpe, J.P.; Clarke, M.R.; Martins, H.R. A preliminary biochemical genetic investigation of the population structure of Loligo forbesi Streenstrup, 1856 from the British Isles and the Azores. In: Okutani, T.; O'Dor, R.K.; Kubodera, T., eds. Recent advances in cephalopod fishery biology, Tokyo, Japan: Tokai University Press, 1993: 61-69.

12. Brierley, A.S.; Thorpe, J.P.; Pierce, G.J.; Clark, M.R.; Boyle, P.R. Genetic variation in the neritic squid Loligo forbesi (Myopsida: Loliginidae) in the northeast Atlantic Ocean. Mar. Biol. 122: 79-86; 1995.

13. Carvalho, G.R.; Hausser, L. Molecular genetics and the stock concept in fisheries. Rev. Fish. Biol. Fish. 4: 300-326; 1994.

14. Carvalho, G.R.; Loney, K.H. Biochemical genetic studies on the Patagonian squid Loligo gahi d'Orbigny. I. Electrophoretic survey of genetic variability. J. Exp. Mar. Biol. Ecol. 126: 231-241; 1989.

15. Carvalho, G.R.; Nigmatullin, Ch.M. Species identification and stock structure analysis within the genus Illex. In: Rodhouse, P.G.; Dawe, E.G.; O'Dor, R.K., eds. A review of recruitment process in the squid genus Illex. FAO Fish. Tech. Pap.; in press.

16. Carvalho, G.R.; Thompson, A.; Stoner A.L. Genetic diversity and population differentiation of the shortfin squid Illex argentinus in the south-west Atlantic. J. Exp. Mar. Biol. Ecol. 158: 105-121; 1992.

17. Dando, P.R.; Storey, K.B.; Hochachka, P.W.; Storey, J.M. Multiple dehydrogenases in marine molluscs: electrophoretic analysis of alanopine dehydrogenase, strombine 
dehydrogenase, octopine dehydrogenase and lactate dehydrogenase. Mar. Biol. Lett. 2: $249-257 ; 1981$.

18. Dessauer, H.C.; Cole, C.J.; Hafner, M.S. Collection and storage of tissues. In: Hillis, D.M.; Moritz, C., eds. Mollecular systematics. MA, USA: Sinauer Associates; 1990: $25-41$.

19. Dessauer, H.C.; Menzies, R.A. Stability of macromolecules during long term storage. In: Dessauer, H.C.; Hafner, M.S., eds. Collections of frozen tissues. Values, management, field and laboratory procedures, and directory of existing collections. Lawrence, KS: Association of Systematics Collections; 1984: 17-20.

20. Food and Agriculture Organization Yearbook fishery statistics, 1992. 1994. 74 vol.

21. Farris, J.S. Methods for computing Wagner trees. Syst. Zool. 19: 83-92; 1970.

22. Felsenstein, J. PHYL1P. phylogeny inference package, ver. 3.5c. Seattle, WA: J. Felsenstein; 1993.

23. Fildes, R.A.; Harris, H. Genetically determined variation of adenylate kinase in man. Nature 209: 261-263; 1966.

24. Gäde, G. A comparative study of octopine dehydrogenase isoenzymes in gastropod, bivalve and cephalopod molluscs. Comp. Biochem. Physiol. 67B: 575-582; 1980.

25. Garthwaite, R.L.; Berg Jr., C.J.; Harrigan, J. Population genetics of the common squid Loligo pealei LeSueur, 1821, from Cape Cod to Cape Hatteras. Biol. Bull. 177: 287-294; 1989.

26. Guerra, A. Mollusca, cephalopoda. In: Ramos, M.A.; Alba, J.; Belles, X.; Gosalbez, J.; Guerra, A.; Macpherson, E.; Martin, F.; Serrano, J.; Templado, J., eds. Fauna Iberica, Madrid: Museo Nacional de Ciencias Naturales, CSIC; 1992, 1 vol.

27. Harris, H.; Hopkinson, D.A. Handbook of enzyme electrophoresis in human genetics. Amsterdam: North-Holland; 1976.

28. Hatanaka, H.; O'Dor, R.K.; Roper, C.F.E. Population structure session. In: Okutani, T.; O'Dor, R.K.; Kubodera, T., eds. Recent advances in cephalopod fishery biology, Tokyo, Japan: Tokai University Press, 1993: 721-739.

29. International Union of Biochemistry and Molecular Biology, Nomenclature committee. Enzyme Nomenclature, 1992. Academic Press; 1992.

30. Katugin, O.N. Genetic variation in the squid Berryteuthis magister (Berry, 1913), (Oegopsida: Gonatidae). In: Okutani, T.; O'Dor, R.K.; Kubodera, T., eds. Recent advances in cephalopod fishery biology, Tokyo, Japan: Tokai University Press, 1993: 201-213. 
31. Khromov, D.N. Systematics and phylogeny of the cuttlefish, Family Sepiidae, (Cephalopoda). Zool. Z. J. 61: 1164-1176; 1987.

32. Khromov, D.N.; Lu, C.C.; Guerra, A.; Dong, Z.Z; Boletzky, S.v. A synopsis of Sepiidae outside Australian waters (Cephalopoda: Sepioidea). In: Voss, N.A. et al., ed. Systematics and biogeography of cephalopods, Smithsonian Institution, Washington, D.C.: Smithsonian Contributions to Zoology Series; in press.

33. Kluge, A.G.; Farris, J.D. Quantitative phyletics and the evolution of anurans. Syst. Zool. 18: 1-32; 1969.

34. Morizot, D.C.; Schmidt, M.E. Starch gel electrophoresis and histochemical visualization of proteins. In: Whitmore, D.H., ed. Electrophoretic and isoelectric focusing techniques in fisheries management, Boca Raton: CRC Press; 1990: 23-80.

35. Murphy, R.W.; Sites Jr., C.W.; Both, D.G.; Haufler, C.H. Proteins I: isozyme electrophoresis. In: Hillis, D.M.; Moritz, C., eds. Mollecular systematics, MA, USA: Sinauer Associates; 1990: 45-126.

36. Nei, M. Molecular evolutionary genetics. New York: Columbia University Press; 1987.

37. Nevo, E.; Beiles, A.; Ben-Shlomo, R. The evolutionary of genetic diversity: ecological, demographic and life history correlates. In: Mani, G.S., ed. Evolutionary dynamics of genetic diversity, New York: Springer-Verlag; 1984: 13-213.

38. Olomucki, A.; Huc, C.; Lefebure, F.; van Thoai, N. Octopine dehydrogenase. Evidence for a single-chain structure. Eur. J. Biochem. 28: 261-268; 1972.

39. Pasteur, N.; Pasteur, G.; Bonhonme, F.; Catalan, J.; Britton-Davidian, J. Manual Technique de Genetique par Electrophorese des Proteines, Technique et Documentation, Paris, 1987. In: Practical isozyme genetics, Chichester: Ellis Horwood Limited; 1988: 215.

40. Santulli, A.; Wilkins, N.P.; D'Amelio, V. Two tissue-specific loci for octopine dehydrogenase in Tapes decussatus (Bivalvia, Veneridae). Comp. Biochem. Physiol. 102B: 409-411; 1992.

41. Sato, M.; Takeuchi, M.; Kanno, N.; Nagahisa, E.; Sato, Y. Distribution of opine dehydrogenases activities in marine animals. Comp. Biochem. Physiol. 106B: 955960; 1993.

42. Selander, R.K.; Smith, M.H.; Yang, S.Y.; Johnson, W.E.; Gentry, J.B. Biochemical polymorphism and systematics in the genus Peromyscus. I Variation in the old-fled 
mouse (Peromyscus polionotus). In: Studies in genetics VI. University of Texas Publications 7103, Austin: University of Texas; 1971: 49-90.

43. Shaklee, J.B.; Allendorf, F.W.; Morizot, D.C.; Whitt, G.S. Gene nomenclature for protein-coding loci in fish. Trans. Am. Fish. Soc. 119: 2-15; 1990.

44. Shaw, C.R.; Prasad, R. Starch gel electrophoresis of enzymes. A compilation of recipes. Biochem. Genet. 4: 297-320; 1970.

45. Storey, K.B. Purification and characterization of arginine kinase from the mantle muscle of the squid Symplectoteuthis oualensis. Role of the phosphagen/phosphagen kinase system in a highly aerobic muscle. Archs. Biochem. Biophys. 179: 518-526; 1977.

46. Storey, K.B. Tissue specific isozymes of octopine dehydrogenase in the cuttlefish, Sepia officinalis. The roles of octopine dehydrogenase and lactate dehydrogenase in Sepia. J. comp. Physiol.115: 159-169; 1977.

47. Storey, K.B.; Storey, J.M. Kinetic characterization of tissue specific isozymes of octopine dehydrogenase from mantle muscle and brain of Sepia officinalis. Eur. J. Biochem. 93: 545-552; 1979.

48. Ward, R.D.; Beardmore, J.A. Protein variation in the plaice. Pleuronectes platessa. Genet. Res. 30: 45-62; 1977.

49. Whitmore, D.H., editor. Electrophoretic and isoelectric focusing techniques in fisheries management. Boca Raton: CRC Press; 1990.

50. Yeatman, J.; Benzie, J.A.H. Genetic structure and distribution of Photololigo spp. in Australia. Mar. Biol. 118: 79-87; 1994 
FIG. 1. Map of the Galician coast (A), NW Iberian Peninsula, showing the fishing ports (Celeiro, Ribeira and Vigo) where the samples of Sepia officinalis, S. orbignyana, and S. elegans were collected from commercial lots.

FIG. 2. Zymogram corresponding to the AAT.1* and AAT.2* loci for three specimens of Sepia orbignyana (a, b, c) using freshly. caught samples $(0 \mathrm{~h})$ and samples kept for 6 $\mathrm{h}, 12 \mathrm{~h}$, and $24 \mathrm{~h}$ at room temperature of the digestive gland $(\mathrm{dg})$ and the mantle muscle (m). O: origin; +: anode.

FIG. 3. The most parsimonius tree found for Sepia officinalis, S. orbignyana, and S. elegans employing the Wagner parsimony method. The ommastrephid species Illex coindetii was used as outgroup to root the tree.

TABLE 1. Resolved enzymes (abbreviations), E.C. numbers, most effective buffer systems, electrophoretic conditions (V/cm and time (hours) of migration), number of detected loci and quaternary structures for the isozymes of the mantle muscle and the digestive gland in Sepia officinalis, S. orbignyana, and S. elegans

\begin{tabular}{lllllll}
\hline Enzyme & E.C. & Buffer system & V/cm & Time & No Loci & Structure \\
\hline AAT & 2.6 .1 .1 & B & 5.4 & 17 & 2 & $-/ \mathrm{d}$ \\
ACP & 3.1 .3 .2 & B & 4.6 & 12 & 3 & $-/-/ m$ \\
AK & 2.7 .4 .3 & B & 5.4 & 9 & 1 & - \\
ARK & 2.7 .3 .3 & B & 5.4 & 12 & 1 & - \\
DDH & 1.8 .1 .4 & A & 10.0 & 9 & 1 & m \\
EST & $3.1 .1 .-$ & B & 5.4 & 9 & 3 & - \\
ESTD & 3.1 .1 .56 & B & 5.4 & 12 & 1 & $\mathrm{~d}$ \\
FBALD & 4.1 .2 .13 & B & 4.6 & 9 & 1 & - \\
G3PDH & 1.1 .1 .8 & A & 12.3 & 12 & 1 & - \\
GLUDH & 1.4 .1 .2 & A & 12.3 & 9 & 1 & - \\
GPI & 5.3 .1 .9 & A & 12.3 & 15 & 2 & $-/ d$ \\
IDDH & 1.1 .1 .14 & B & 5.4 & 12 & 1 & t \\
IDHP & 1.1 .1 .42 & B & 5.4 & 12 & 2 & $\mathrm{~d} / \mathrm{d}$ \\
LAP & 3.4 .11 .1 & B & 5.4 & 12 & 1 & - \\
LDH & 1.1 .1 .27 & B & 5.4 & 15 & 1 & - \\
\hline
\end{tabular}




\begin{tabular}{lllllll}
\hline MDH & 1.1 .1 .37 & B & 5.4 & 12 & 2 & - \\
MEP & 1.1 .1 .40 & A & 12.3 & 12 & 2 & - \\
MPI & 5.3 .1 .8 & A & 12.3 & 12 & 1 & - \\
OPDH & 1.5 .1 .11 & A & 12.3 & 15 & 2 & $\mathrm{~m} /-$ \\
PEPA & 3.4 .13 .18 & A & 12.3 & 12 & 1 & - \\
PEPB & 3.4 .11 .4 & A & 12.3 & 12 & 1 & $\mathrm{~m}$ \\
PEPD & 3.4 .13 .9 & A & 12.3 & 12 & 1 & - \\
PGDH & 1.1 .1 .44 & B & 5.4 & 12 & 1 & - \\
PGM & 5.4 .2 .2 & B & 5.4 & 12 & 1 & $\mathrm{~m}$ \\
PK & 2.7 .1 .40 & B & 5.4 & 15 & 2 & - \\
SOD & 1.15 .1 .1 & B & 5.4 & 9 & 1 & - \\
\hline
\end{tabular}

PEPA (substrate: gly-leu); PEPB (substrate: leu-gly-gly); PEPD (substrate: phe-pro).

Buffer systems: A, Tris-Borate-EDTA pH 8.7 (gel buffer dilution 1:4); B, Tris-Citrate pH 8.0 (gel buffer dilution 1:9). The quaternary structures are indicated for each isozyme whenever heterozygotes were observed $(-=$ heterozygotes not observed, $\mathrm{m}=$ monomeric structure, $\mathrm{d}=$ dimeric structure, $\mathrm{t}=$ tetrameric structure). 
TABLE 2. Relative enzyme activities for 37 isozymes from freshly-caught samples $(0 \mathrm{~h})$ and samples kept for $6 \mathrm{~h}, 12 \mathrm{~h}$ (only for the digestive gland) and $24 \mathrm{~h}$ at room temperature in the mantle muscle and the digestive gland of Sepia officinalis and S. orbignyana. The total number of isozymes with no detectable enzyme activity (nd isozymes), and with varying enzyme activity (A_ isozymes), are also given for each species, tissue and time. $\mathrm{nd}=$ no detectable, $\mathrm{A} 1=$ weak, $\mathrm{A} 2$ = moderate, $\mathrm{A} 3=$ strong

\begin{tabular}{|c|c|c|c|c|c|c|c|c|c|c|c|c|c|c|}
\hline \multirow[b]{3}{*}{ Isozyme } & \multicolumn{7}{|c|}{ Sepia officinalis } & \multicolumn{7}{|c|}{ Sepia orbignyana } \\
\hline & \multicolumn{4}{|c|}{ Digestive gland } & \multicolumn{3}{|c|}{ Mantle muscle } & \multicolumn{4}{|c|}{ Digestive gland } & \multicolumn{3}{|c|}{ Mantle muscle } \\
\hline & Oh & $6 \mathrm{~h}$ & $12 \mathrm{~h}$ & $24 \mathrm{~h}$ & $0 \mathrm{~h}$ & $6 \mathrm{~h}$ & $24 \mathrm{~h}$ & $\mathrm{Oh}$ & $6 \mathrm{~h}$ & $12 \mathrm{~h}$ & $24 \mathrm{~h}$ & Oh & $6 \mathrm{~h}$ & $24 \mathrm{~h}$ \\
\hline AAT-1 & A3 & A3 & A3 & A2 & A3 & A3 & $\mathrm{A} 2$ & $\mathrm{~A} 2$ & A1 & nd & nd & A3 & A3 & $\mathrm{A} 2$ \\
\hline AAT-2 & $\mathrm{A} 2$ & $\mathrm{~A} 2$ & A2 & A1 & A2 & A2 & $\mathrm{A} 2$ & A2 & $\mathrm{A} 2$ & A1 & A1 & $\mathrm{A} 2$ & $\mathrm{~A} 2$ & $\mathrm{~A} 2$ \\
\hline ACP-1 & A2 & $\mathrm{A} 2$ & $\mathrm{~A} 2$ & $\mathrm{~A} 2$ & nd & nd & nd & A1 & A1 & A1 & A1 & nd & nd & nd \\
\hline ACP-2 & $\mathrm{A} 2$ & $\mathrm{~A} 2$ & $\mathrm{~A} 2$ & $\mathrm{~A} 2$ & nd & nd & nd & A1 & A1 & $\mathrm{A} 1$ & nd & nd & nd & nd \\
\hline ACP-3 & A3 & A3 & A3 & A3 & A2 & A2 & $\mathrm{A} 2$ & A3 & A3 & A3 & A3 & $\mathrm{A} 2$ & $\mathrm{~A} 2$ & $\mathrm{~A} 2$ \\
\hline $\mathrm{AK}$ & $\mathrm{A} 2$ & $\mathrm{~A} 2$ & nd & nd & A2 & A2 & $\mathrm{A} 2$ & nd & nd & nd & nd & A2 & A2 & A2 \\
\hline ARK & $\mathrm{A} 2$ & A2 & A1 & nd & A3 & A3 & A3 & A1 & nd & nd & nd & A3 & A3 & $\mathrm{A} 2$ \\
\hline $\mathrm{DDH}$ & A2 & A2 & A2 & A1 & A1 & A1 & A1 & A2 & A2 & A1 & A1 & A1 & A1 & A1 \\
\hline EST-1 & $\mathrm{A} 2$ & $\mathrm{~A} 2$ & A1 & nd & nd & nd & nd & $\mathrm{A} 2$ & $\mathrm{~A} 2$ & $\mathrm{~A} 2$ & $\mathrm{~A} 2$ & nd & nd & nd \\
\hline EST-2 & A2 & A2 & A1 & A1 & $\mathrm{A} 2$ & $\mathrm{~A} 2$ & $\mathrm{~A} 2$ & A3 & A3 & $\mathrm{A} 3$ & A2 & $\mathrm{A} 2$ & A2 & A1 \\
\hline EST-3 & A2 & A2 & A2 & A2 & nd & nd & nd & A3 & A3 & $\mathrm{A} 3$ & A3 & nd & nd & nd \\
\hline ESTD & A3 & A3 & A3 & A2 & A2 & $\mathrm{A} 2$ & $\mathrm{~A} 2$ & A3 & A3 & A3 & A3 & A2 & $\mathrm{A} 2$ & A2 \\
\hline
\end{tabular}




\begin{tabular}{|c|c|c|c|c|c|c|c|c|c|c|c|c|c|c|}
\hline FBALD & nd & nd & nd & nd & $\mathrm{A} 2$ & $\mathrm{~A} 2$ & $\mathrm{~A} 2$ & ND & nd & nd & nd & $\mathrm{A} 2$ & $\mathrm{~A} 2$ & A1 \\
\hline G3PDH & $\mathrm{A} 3$ & $\mathrm{~A} 3$ & $\mathrm{~A} 2$ & nd & $\mathrm{A} 3$ & $\mathrm{~A} 3$ & $\mathrm{~A} 3$ & $\mathrm{~A} 1$ & nd & nd & nd & $\mathrm{A} 3$ & $\mathrm{~A} 3$ & A 3 \\
\hline GLUDH & nd & nd & nd & nd & A 1 & A1 & A1 & nd & nd & nd & nd & A1 & A1 & A1 \\
\hline GPI-1 & $\mathrm{A} 2$ & $\mathrm{~A} 2$ & A1 & nd & $\mathrm{A} 2$ & $\mathrm{~A} 2$ & $\mathrm{~A} 2$ & nd & nd & nd & nd & $\mathrm{A} 2$ & $\mathrm{~A} 2$ & A2 \\
\hline GPI-2 & nd & nd & nd & nd & $\mathrm{A} 2$ & $\mathrm{~A} 2$ & $\mathrm{~A} 2$ & nd & nd & nd & nd & $\mathrm{A} 2$ & $\mathrm{~A} 2$ & A 2 \\
\hline IDDH & $\mathrm{A} 2$ & $\mathrm{~A} 2$ & $\mathrm{~A} 2$ & A1 & $\mathrm{A} 2$ & $\mathrm{~A} 2$ & $\mathrm{~A} 2$ & A1 & nd & nd & nd & $\mathrm{A} 2$ & $\mathrm{~A} 2$ & A2 \\
\hline IDHP-1 & $\mathrm{A} 2$ & $\mathrm{~A} 2$ & $\mathrm{~A} 2$ & nd & $\mathrm{A} 2$ & $\mathrm{~A} 2$ & A1 & nd & nd & nd & nd & nd & nd & nd \\
\hline IDHP-2 & $\mathrm{A} 2$ & $\mathrm{~A} 2$ & $\mathrm{~A} 1$ & nd & $\mathrm{A} 3$ & $\mathrm{~A} 3$ & $\mathrm{~A} 3$ & $\mathrm{~A} 1$ & nd & nd & nd & $\mathrm{A} 3$ & $\mathrm{~A} 3$ & A 3 \\
\hline LAP & $\mathrm{A} 3$ & $\mathrm{~A} 3$ & $\mathrm{~A} 3$ & $\mathrm{~A} 3$ & A2 & $\mathrm{A} 2$ & A2 & $\mathrm{A} 3$ & A3 & $\mathrm{A} 3$ & $\mathrm{~A} 2$ & $\mathrm{~A} 2$ & $\mathrm{~A} 2$ & A2 \\
\hline LDH & $\mathrm{A} 3$ & $\mathrm{~A} 3$ & $\mathrm{~A} 3$ & $\mathrm{~A} 3$ & nd & nd & nd & $\mathrm{A} 3$ & A3 & $\mathrm{A} 2$ & $\mathrm{~A} 1$ & nd & nd & nd \\
\hline MDH-1 & $\mathrm{A} 2$ & $\mathrm{~A} 2$ & $\mathrm{~A} 2$ & $\mathrm{~A} 1$ & $\mathrm{~A} 2$ & $\mathrm{~A} 2$ & $\mathrm{~A} 2$ & $\mathrm{~A} 2$ & nd & nd & nd & $\mathrm{A} 2$ & $\mathrm{~A} 2$ & A 2 \\
\hline MDH-2 & $\mathrm{A} 2$ & $\mathrm{~A} 2$ & A1 & nd & $\mathrm{A} 2$ & $\mathrm{~A} 2$ & A1 & A1 & nd & nd & nd & $\mathrm{A} 2$ & $\mathrm{~A} 2$ & $\mathrm{~A} 2$ \\
\hline MEP-1 & $\mathrm{A} 2$ & $\mathrm{~A} 2$ & $\mathrm{~A} 2$ & $\mathrm{~A} 1$ & $\mathrm{~A} 2$ & $\mathrm{~A} 2$ & $\mathrm{~A} 2$ & $\mathrm{~A} 2$ & A1 & nd & nd & $\mathrm{A} 2$ & $\mathrm{~A} 2$ & A 2 \\
\hline MEP-2 & nd & nd & nd & nd & nd & nd & nd & $\mathrm{A} 2$ & A1 & nd & nd & A1 & A1 & A1 \\
\hline MPI A3 & $\mathrm{A} 3$ & A3 & $\mathrm{A} 3$ & $\mathrm{~A} 2$ & $\mathrm{~A} 3$ & $\mathrm{~A} 3$ & A3 & $\mathrm{A} 2$ & A1 & nd & nd & $\mathrm{A} 2$ & $\mathrm{~A} 2$ & A 2 \\
\hline OPHD-1 & nd & nd & nd & nd & $\mathrm{A} 2$ & $\mathrm{~A} 2$ & $\mathrm{~A} 2$ & nd & nd & nd & nd & A1 & A1 & A 1 \\
\hline OPHD-2 & nd & nd & nd & nd & $\mathrm{A} 3$ & $\mathrm{~A} 3$ & A3 & nd & nd & nd & nd & $\mathrm{A} 3$ & $\mathrm{~A} 3$ & A3 \\
\hline PEPA & $\mathrm{A} 3$ & $\mathrm{~A} 2$ & $\mathrm{~A} 1$ & nd & $\mathrm{A} 2$ & $\mathrm{~A} 2$ & $\mathrm{~A} 2$ & $\mathrm{~A} 1$ & nd & nd & nd & $\mathrm{A} 2$ & $\mathrm{~A} 2$ & A 2 \\
\hline PEPB & A3 & A3 & A3 & A3 & $\mathrm{A} 2$ & $\mathrm{~A} 2$ & $\mathrm{~A} 2$ & A3 & A3 & A3 & $\mathrm{A} 2$ & $\mathrm{~A} 2$ & $\mathrm{~A} 2$ & A2 \\
\hline PEPD & $\mathrm{A} 3$ & A3 & $\mathrm{A} 3$ & A3 & $\mathrm{A} 2$ & $\mathrm{~A} 2$ & $\mathrm{~A} 2$ & $\mathrm{~A} 3$ & $\mathrm{~A} 2$ & $\mathrm{~A} 2$ & $\mathrm{~A} 1$ & $\mathrm{~A} 2$ & $\mathrm{~A} 2$ & $\mathrm{~A} 2$ \\
\hline
\end{tabular}




\begin{tabular}{lllllllllllllll}
\hline PGDH & A2 & A2 & A1 & nd & A2 & A2 & A2 & A2 & nd & nd & nd & A2 & A2 & A2 \\
PGM & A2 & A2 & A1 & nd & A2 & A2 & A2 & A2 & A1 & nd & nd & A2 & A2 & A2 \\
PK-1 & nd & nd & nd & nd & A2 & A2 & A2 & nd & nd & nd & nd & A2 & A2 & A1 \\
PK-2 & nd & nd & nd & nd & A3 & A3 & A3 & nd & nd & nd & nd & A3 & A3 & A2 \\
SOD & A2 & A2 & A2 & A1 & A1 & A1 & A1 & A2 & A2 & A2 & A2 & A1 & A1 & A1 \\
nd isozymes & 8 & 8 & 9 & 19 & 6 & 6 & 6 & 10 & 18 & 23 & 24 & 6 & 6 & 6 \\
A_isozymes & 29 & 29 & 28 & 18 & 31 & 31 & 31 & 27 & 19 & 14 & 13 & 31 & 31 & 31 \\
\hline
\end{tabular}


TABLE 3. Allele frequencies for 32 presumptive loci from mantle muscle in Sepia officinalis (Sof), S. orbignyana (Sor), S. elegans (Sel), and Illex coindetii (Ico). The number of individuals assayed was ten for each locus and species.

\begin{tabular}{|c|c|c|c|c|c|}
\hline Locus & Allele & Sof & Sor & Sel & Ico \\
\hline \multirow[t]{4}{*}{ AAT-1* } & $* 90$ & 0 & 0 & 0 & 1 \\
\hline & $* 100$ & 1 & 0 & 0 & 0 \\
\hline & $* 110$ & 0 & 1 & 0 & 0 \\
\hline & $* 120$ & 0 & 0 & 1 & 0 \\
\hline \multirow[t]{5}{*}{$\mathrm{AAT}-2 *$} & $* 20$ & 0 & 0.75 & 0 & 0 \\
\hline & $* 80$ & 0 & 0.25 & 0.85 & 0 \\
\hline & $* 100$ & 1 & 0 & 0 & 0 \\
\hline & $* 110$ & 0 & 0 & 0.15 & 0 \\
\hline & $* 120$ & 0 & 0 & 0 & 1 \\
\hline \multirow[t]{5}{*}{$\mathrm{ACP}-3 *$} & $* 50$ & 0 & 0 & 1 & 0 \\
\hline & $* 90$ & 0 & 0.15 & 0 & 0 \\
\hline & $* 100$ & 1 & 0 & 0 & 0 \\
\hline & $* 120$ & 0 & 0 & 0 & 1 \\
\hline & $* 140$ & 0 & 0.85 & 0 & 0 \\
\hline \multirow[t]{3}{*}{$\mathrm{AK}^{*}$} & $* 100$ & 1 & 0 & 0 & 0 \\
\hline & $* 120$ & 0 & 1 & 1 & 0 \\
\hline & $* 300$ & 0 & 0 & 0 & 1 \\
\hline \multirow[t]{3}{*}{$\mathrm{ARK}^{*}$} & $* 80$ & 0 & 0 & 0 & 1 \\
\hline & $* 90$ & 0 & 1 & 1 & 0 \\
\hline & $* 100$ & 1 & 0 & 0 & 0 \\
\hline \multirow[t]{4}{*}{$\mathrm{DDH}^{*}$} & $* 100$ & 1 & 0 & 0 & 0 \\
\hline & $* 110$ & 0 & 0 & 0 & 1 \\
\hline & $* 120$ & 0 & 0.95 & 1 & 0 \\
\hline & $* 130$ & 0 & 0.05 & 0 & 0 \\
\hline \multirow[t]{2}{*}{ EST-2* } & $* 100$ & 1 & 1 & 1 & 0 \\
\hline & $* 120$ & 0 & 0 & 0 & 1 \\
\hline \multirow[t]{2}{*}{ ESTD* } & $* 50$ & 0 & 0 & 0.05 & 0 \\
\hline & $* 60$ & 0 & 1 & 0.15 & 0 \\
\hline
\end{tabular}




\begin{tabular}{|c|c|c|c|c|c|}
\hline & $* 70$ & 0 & 0 & 0 & 1 \\
\hline & $* 80$ & 0 & 0 & 0.80 & 0 \\
\hline & $* 100$ & 1 & 0 & 0 & 0 \\
\hline \multirow[t]{3}{*}{ FBALD } & $* 100$ & 1 & 0 & 0 & 0 \\
\hline & *105 & 0 & 1 & 0 & 1 \\
\hline & $* 120$ & 0 & 0 & 1 & 0 \\
\hline \multirow[t]{3}{*}{ G3PDH* } & $* 60$ & 0 & 0 & 0 & 1 \\
\hline & $* 100$ & 1 & 0 & 0 & 0 \\
\hline & $* 120$ & 0 & 0 & 1 & 0 \\
\hline \multirow[t]{3}{*}{ GLUDH* } & $* 100$ & 1 & 0 & 0 & 0 \\
\hline & $* 120$ & 0 & 1 & 1 & 0 \\
\hline & $* 200$ & 0 & 0 & 0 & 1 \\
\hline \multirow[t]{4}{*}{ GPI-1* } & $* 50$ & 0 & 0 & 1 & 0 \\
\hline & $* 90$ & 0 & 1 & 0 & 0 \\
\hline & $* 100$ & 1 & 0 & 0 & 0 \\
\hline & *110 & 0 & 0 & 0 & 1 \\
\hline \multirow[t]{5}{*}{ GPI-2* } & $* 50$ & 0 & 0 & 0.95 & 0 \\
\hline & $* 70$ & 0 & 0 & 0.05 & 0 \\
\hline & $* 90$ & 0 & 1 & 0 & 0 \\
\hline & $* 100$ & 0 & 0 & 0 & 1 \\
\hline & *110 & 0 & 0 & 0 & 1 \\
\hline \multirow[t]{5}{*}{$\mathrm{IDDH}^{*}$} & $* 50$ & 0 & 0 & 0 & 1 \\
\hline & $* 70$ & 0 & 0 & 0.35 & 0 \\
\hline & $* 80$ & 0.30 & 0 & 0 & 0 \\
\hline & $* 100$ & 0.70 & 1 & 0 & 0 \\
\hline & *110 & 0 & 0 & 0.065 & 0 \\
\hline \multirow[t]{2}{*}{ IDHP-1* } & $* 80$ & 0.05 & - & - & - \\
\hline & $* 100$ & 0.95 & - & - & - \\
\hline \multirow[t]{5}{*}{ IDHP-2* } & $* 100$ & 1 & 0 & 0 & 0 \\
\hline & $* 130$ & 0 & 0.95 & 0 & 0 \\
\hline & *140 & 0 & 0 & 1 & 0 \\
\hline & $* 150$ & 0 & 0.05 & 0 & 0 \\
\hline & $* 250$ & 0 & 0 & 0 & 1 \\
\hline
\end{tabular}




\begin{tabular}{|c|c|c|c|c|c|}
\hline \multirow[t]{4}{*}{ LAP* } & $* 50$ & 0 & 0 & 1 & 0 \\
\hline & $* 80$ & 0 & 0 & 0 & 1 \\
\hline & $* 90$ & 0 & 1 & 0 & 0 \\
\hline & $* 100$ & 1 & 0 & 0 & 0 \\
\hline \multirow[t]{4}{*}{ MDH-1* } & $* 90$ & 0 & 0 & 1 & 0 \\
\hline & $* 100$ & 1 & 0 & 0 & 0 \\
\hline & $* 110$ & 0 & 0 & 0 & 1 \\
\hline & $* 120$ & 0 & 1 & 0 & 0 \\
\hline \multirow[t]{2}{*}{ MDH-2* } & $* 100$ & 1 & 1 & 1 & 0 \\
\hline & $* 120$ & 0 & 0 & 0 & 1 \\
\hline \multirow[t]{3}{*}{ MEP-1* } & $* 100$ & 1 & 0 & 0 & 0 \\
\hline & $* 110$ & 0 & 1 & 1 & 0 \\
\hline & $* 120$ & 0 & 0 & 0 & 1 \\
\hline MEP-2* & $* 100$ & - & 1 & 1 & - \\
\hline \multirow[t]{3}{*}{ MPI* } & $* 70$ & 0 & 0 & 0 & 1 \\
\hline & $* 90$ & 0 & 1 & 1 & 0 \\
\hline & $* 100$ & 1 & 0 & 0 & 0 \\
\hline \multirow[t]{6}{*}{ OPDH-1* } & $* 50$ & 0 & 0 & 0.75 & 0 \\
\hline & $* 60$ & 0 & 0.90 & 0 & 0 \\
\hline & $* 80$ & 0 & 0.10 & 0.25 & 0 \\
\hline & $* 100$ & 0.80 & 0 & 0 & 0 \\
\hline & $* 120$ & 0.20 & 0 & 0 & 0 \\
\hline & $* 140$ & 0 & 0 & 0 & 1 \\
\hline \multirow[t]{4}{*}{ OPDH-2* } & $*-50$ & 0 & 0 & 0 & 1 \\
\hline & $* 40$ & 0 & 0 & 1 & 0 \\
\hline & $* 50$ & 0 & 1 & 0 & 0 \\
\hline & $* 100$ & 1 & 0 & 0 & 0 \\
\hline \multirow[t]{2}{*}{ PEPA* } & $* 100$ & 1 & 1 & 1 & 0 \\
\hline & $* 130$ & 0 & 0 & 0 & 1 \\
\hline \multirow[t]{3}{*}{ PEPB* } & $* 80$ & 0 & 0 & 0 & 1 \\
\hline & $* 100$ & 1 & 0 & 0.10 & 0 \\
\hline & $* 120$ & 0 & 1 & 0.90 & 0 \\
\hline PEPD* & $* 40$ & 0 & 0 & 0 & 1 \\
\hline
\end{tabular}




\begin{tabular}{|c|c|c|c|c|c|}
\hline & $* 80$ & 0 & 1 & 0 & 0 \\
\hline & $* 100$ & 1 & 0 & 1 & 0 \\
\hline \multirow[t]{4}{*}{ PGDH* } & $* 30$ & 0 & 0 & 1 & 0 \\
\hline & $* 60$ & 0 & 1 & 0 & 0 \\
\hline & $* 100$ & 1 & 0 & 0 & 0 \\
\hline & *200 & 0 & 0 & 0 & 1 \\
\hline \multirow[t]{5}{*}{ PGM* } & $* 60$ & 0 & 0 & 0 & 0.95 \\
\hline & $* 100$ & 1 & 0 & 0 & 0.05 \\
\hline & *200 & 0 & 1 & 0 & 0 \\
\hline & *220 & 0 & 0 & 0.95 & 0 \\
\hline & $* 240$ & 0 & 0 & 005 & 0 \\
\hline \multirow[t]{3}{*}{ PK-1* } & $* 50$ & 0 & 0 & 0 & 1 \\
\hline & $* 100$ & 1 & 0 & 0 & 0 \\
\hline & $* 110$ & 0 & 1 & 1 & 0 \\
\hline \multirow[t]{3}{*}{ PK-2* } & $* 70$ & 0 & 0 & 1 & 1 \\
\hline & $* 90$ & 0 & 1 & 0 & 0 \\
\hline & $* 100$ & 1 & 0 & 0 & 0 \\
\hline \multirow[t]{3}{*}{ SOD* } & *90 & 0 & 1 & 1 & 0 \\
\hline & $* 100$ & 1 & 0 & 0 & 0 \\
\hline & $* 120$ & 0 & 0 & 0 & 1 \\
\hline
\end{tabular}

TABLE 4. Average hererozygosities $(\mathrm{H})$, average number of alleles $(\mathrm{Na})$ with their standard errors (SE), and proportion of polymorphic loci using the 0.95 criterion $(\mathrm{P})$ are shown for each species

\begin{tabular}{lllll}
\hline & S. officinalis & S. orbignyana & S. elegans & I. coindetii \\
\hline $\mathrm{H}(\mathrm{SE})$ & $0.028(0.017)$ & $0.034(0.015)$ & $0.061(0.022)$ & $0.003(0.001)$ \\
$\mathrm{Na}(\mathrm{SE})$ & $1.10(0.05)$ & $1.16(0.07)$ & $1.26(0.09)$ & $1.03(0.03)$ \\
$\mathrm{P}$ & 0.097 & 0.161 & 0.226 & 0.033 \\
\hline
\end{tabular}

